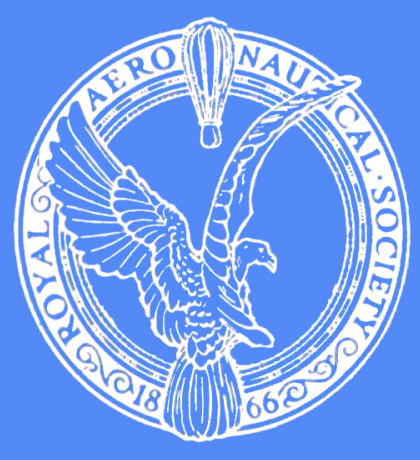

INCLUDING

SUPPLEMENTARY

PAPERS

\title{
THE
}

AERONAUTICAL JOURNAL

JUNE 1969

NOTICES

BRANCHES

GRADUATES' AND STUDENTS' SECTION

A. Stratton LOOKING AHEAD IN AERONAUTICS-19: AIR TRAFFIC AND NAVIGATION IN THE SECOND CENTURY

P. Martin IN DEFENCE OF PRIVATE, BUSINESS AND AERIAL WORK FLYING

AIR TRANSPORT GROUP SYMPOSIUM ON AIRPORTS AND TRANSPORT AIRCRAFT: INTER-RELATIONS AND INTER-FACE PROBLEMS

THE WOMEN'S ENGINEERING SOCIETY

TECHNICAL NOTES

R. K. Penny

M. C. Mathur

R. T. Griffiths and C. Y. Ma
The Creep of Pressurised Cylindrical Shells

The Static Stability of a Cone-Cylinder Flare and Two Cone-Cylinder Fin-Flare Combinations at Supersonic Speed

Differential Boundary-Layer Separation Effects in the Flow over a Rotating Cylinder

THE LIBRARY

Reviews: The Great Air War-Aircraft Stability and Control for Pilots and Engineers-Lion in the Sky-A Bibliography of Refractory Metals-Advanced Mechanics_Aircraft '69-Analogue Computers-Review of the Soviet Space Program-The Promise of Space

Additions to the Library. Reports

\section{SUPPLEMENTARY PAPERS}

THE AERODYNAMICS OF HIGH-LIFT DEVICES ON CONVENTIONAL AIRCRAFT

D. M. McRae Part I. General Description and Comments on $\mathrm{C}_{\mathrm{L} \max }$ and Stalling Behaviour

D. N. Foster Part II. Some Aspects of the RAE High-Lift Research Programme

H. W. Pout THE EVOLUTION OF GUIDED WEAPONS

\section{THE ROYAL AERONAUTICAL SOCIETY}

\section{HAMILTON PLACE LONDON W1}




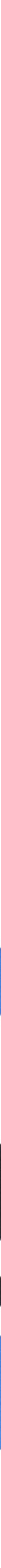

Only Decca/Omnitrac provides accurate three dimensional navigation. The system incorporates a closed-loop servo-driven display head providing a track trace on conventional charts and is the first system to offer vertical guidance readout.

\section{Closed lloop}

Digital servos continuously compare navaid position co-ordinates with corresponding outputs from the computer/display system, not only eliminating the need for manual chart setting, but ensuring complete integrity since the display will reset and update itself, automatically, without error, even after interruption in the drive to the display head. Ordinary, or 'open loop' displays can, without warning to the pilot give false position indication, arising from malfunction due, for example, to increased friction or handling.

\section{Track trace}

One glance at the track trace on the Decca display head tells the pilot not only where he is, but also where he's come from, and the rate at which he is approaching his desired track. He can thus determine navigational trends without the need to integrate successive plot indications. After use the track trace can be quickly erased or photo-printed for the record. With the Decca track trace after only one or two practice runs pilots make smooth,

accurate instrument approaches to within one mile of touchdown.

\section{Vertical guidance}

Vertical guidance is programmed into the Omnitrac computer, for display on the Flight Director. When altitudes required at

waypoints along the route are set into the computer, information is displayed in one of two ways:

EN ROUTE Commands for climb or descent are displayed until the programmed altitude is attained

APPROACH The difference in altitude and distance between two successive waypoints is used to define a flight path or 'glide slope' In this way multiple routes free the pilot from point to point navigation and an extremely in 30 back in the COCKOIt laccurate flight profile can be maintained, Only Decca has real experience with pictorial displays-over $2 \frac{1}{2}$ million flying hours by BEA alone....

\section{The Decca Navigator Company Limited • London}




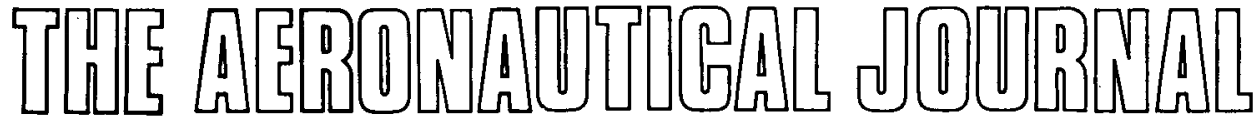

THE ROYAL AERONAUTICAL SOCIETY

Incorporating The Institution of Aeronautical Engineers and The Helicopter Association of Great Britain

Telephone: 01-499 3515 Telegrams: Didaskalos, London, W1

Published Monthly at 4 HAMILTON PLACE, LONDON WIV OBQ

Subscriptions: £15 15s. Od. per annum, post free Single Copies: 27s. 6d.

VOLUME 73

NUMBER 702

JUNE 1969

CONTENTS

NOTICES

Page

BRANCHES

XLVII

GRADUATES' AND STUDENTS' SECTION

A. Stration LOOKING AHEAD IN AERONAUTICS-19: AIR TRAFFIC AND NAVIGATION IN THE SECOND CENTURY

P. Martin IN DEFENCE OF PRIVATE, BUSINESS AND AERIAL WORK FLYING

AIR TRANSPORT GROUP SYMPOSIUM ON AIRPORTS AND TRANSPORT AIRCRAFT: INTER-RELATIONS AND INTER-FACE PROBLEMS

J. V. Block International Airport Planning as Influenced by Aircraft Development

E. J. Dickie

G. S. Hill Economics of Air Operations as Affected by Current Transport Aircraft Design Progress in Air Traffic Control and its Relationship to Airport and Aircraft Development Trends

D. R. Blundell Airport Restrictions as they Affect Airline Planning

E. L. Killip Airport Problems in Flight Operations

G. Davidson

D. Newman

K. S. Lawson

The Airport and the Aircraft in Relation to Loading Problems

Aircraft Design as Determined by Airport Facilities and the Environment

The Influence of the Airport, its Facilities and Environment on Aircraft Design and Operating Economics

THE WOMEN'S ENGINNEERING SOCIETY

TECHNICAL NOTES

R. K. Penny

The Creep of Pressurised Cylindrical Shells

M. C. Mathur

R. T. Griffiths and C. Y. Ma

The Static Stability of a Cone-Cylinder Flare and Two Cone-Cylinder Fin-Flare Combinations at Supersonic Speed

Differential Boundary-Layer Separation Effects in the Flow over a Rotating Cylinder

THE LIBRARY

Reviews: The Great Air War-Aircraft Stability and Control for Pilots and Engineers-Lion in the Sky-A Bib!iography of Refractory Metals-Advanced Mechanics-Aircraft '69-Analogue Computers-Review of the Soviet Space Program-The Promise of Space

Additions to the Library. Reports

\section{SUPPLEMENTARY PAPERS}

THE AERODYNAMICS OF HIGH-LIFT DEVICES ON CONVENTIONAL AIRCRAFT

D. M. McRae Part I. General Description and Comments on $\mathrm{C}_{\mathrm{L} \max }$ and Stalling Behaviour

D. N. Foster Part II. Some Aspects of the RAE High-Lift Research Programme

H. W. Pout THE EVOLUTION OF GUIDED WEAPONS

Editor: JOAN BRUCE, BSC, CEng, AFRAES.

Secretary of the Society: A. M. BALLANTYNE, OBE, TD, BSc, PhD, CEng, HonFCASI, FAIAA, FRAeS.

4 HAMILTON PLACE, LONDON, W1V OBQ. Tel: 01-499 3515.
Advertisements Only:

H. E. SOUTHON

Magazine Advertising Ltd, 184 Fleet Street, London, EC4. Tel: 01-242 0434/5.
Reproduction of any of the papers published in this journal is not permitted without the written consent of the Editor.
None of the papers or paragraphs must be taken as expressing the opinion of the Council unless otherwise stated. 


\title{
The Royal Aeronautical Society
}

\author{
Patron: HER MAJESTY THE QUEEN
}

\section{COUNCIL}

President: AIR COMMODORE F. R. BANKS, CB, OBE, CEng, CGIA, HonfAIAA, HonFRAeS, $\operatorname{RAF}$ (retd)

President-Elect: PROFESSOR J. A. J. BENNETT, DSc, PhD, CEng, FAIAA, HonfRAeS

Vice-Presidents:

SIR ROBERT COCKBURN, KBE, CB, PhD, MSc, CEng, FRAeS

G. S. HISLOP, PhD, BSC, ARCST, CEng, FRAES

S. D. DAVIES, CBE, BSC(Eng), CEng, FRAES

Past Presidents:

A. D. BAXTER, MEng, CEng, FRAeS

SIR MORIEN MORGAN, CB, MA, CEng, FRAES

PROFESSOR D. KEITH-LUCAS, HonDSC, MA, CEng, FRAES

Members:

CAPTAIN E. C. BEARD, CBE, FRAES, RN(retd)

M. J. BRENNAN, BSC, CEng, FRAES

T. T. N. COLERIDGE, BE, CEng, FRAeS (President of the New Zealand Division)

$H$. DAVIES, CB, MSc, CEng, FAIAA, FRAES

G. A. FORD, CEng, AFRAeS (President of the Rhodesia Division)

H. H. GARDNER, HonDSC, BSc, CEng, FRAES

W. F. HILTON, DSc, PhD, DIC, CEng, AFAIAA, FRAES

E. HUTCHINSON, BSc, GradRAeS

(Chairman, Graduates' and Students' Section)

B. P. LAIGHT, MSC, CEng, FRAES

PROFESSOR K. L. C. LEGG, BSc (Eng), BSc, CEng, FRAeS

P. G. MASEFIELD, MA, CENG, HONFAIAA, FRAES

AIR COMMODORE J. R. MORGAN, OBE, BSc(Eng), CEng, FRAeS, RAF(retd)

E. S. MOULT, CBE, PhD, BSC, CENg, FRAES

W. N. NEAT, MA, CEng, FRAeS

L. F. NICHOLSON, CB, MA, CEng, FRAES

D. W. NORMAN, BSc(Aero), GradRAeS

G. K. C. PARDOE, BSC, DLC, CEng, FRAeS (Chairman, Astronautics and Guided Flight Section)

AIR VICE-MARSHAL C. N. S. PRINGLE, CBE, MA, CEng, FRAeS

H. ROBERTS, PhD, BSc DIC, CEng, FRAeS (Chairman, Rotorcraft Section)

A. O. M. VIALLS, BSC, CEng, FRAeS (President of the Southern Africa Division)

G. T. WANSBROUGH-WHITE, ARAES

K. G. WILKINSON, BSC, DIC, ACGI, CEng, FRAeS

J. E. D. WILLIAMS, BSC, FRAES

N. H. WOOD, DCAe, CEng, AFRAES

M. W. WOODS, DPhil, BE, BSc, CEng, FRAeS (President of the Australian Division)

Officers:

Hon. Treasurer: C. F. HUGHESDON, AFC (Associate)

Solicitor: L. A. WINGFIELD, MC, DFC (Hon Companion)

Secretary: A. M. BALLANTYNE, OBE, TD, PhD, BSc, CEng, HonfCASI, FAIAA, FRAeS

Note: The President of each Division and the Chairman of each Section of the Society is a Member of Council by reason of his office. 


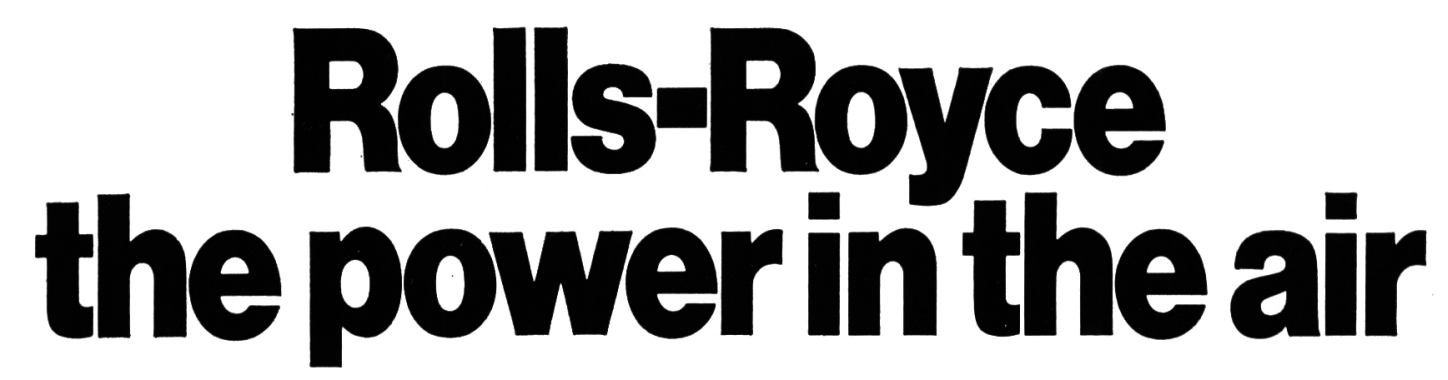

Aircraft powered by Rolls-Royce turbofan, turbojet, turboprop or turboshaft engines are in service with or on order for more than 180 airlines, 250 corporate operators and 60 armed forces all over the world.
Some of these aircraft are shown below.

1. Lockheed L.1011 TriStar-RB.211

2. Concorde-Olympus 593. 3. McDonnell Douglas Phantom-Spey 4. VC10-Conway. 5. Westland Sea King-Gnome

6. Hawker Siddeley Harrier V/STOL-Pegasus.
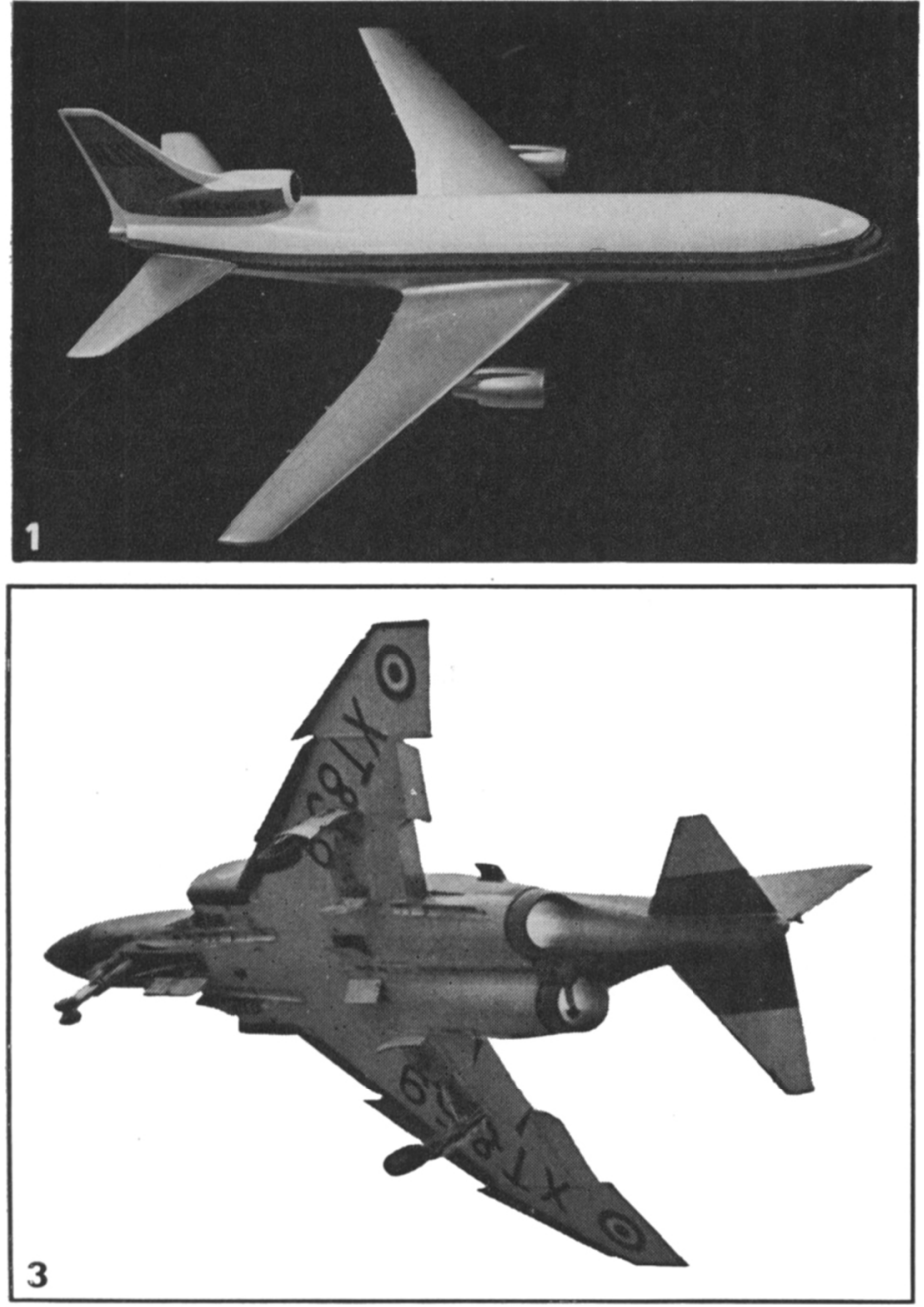
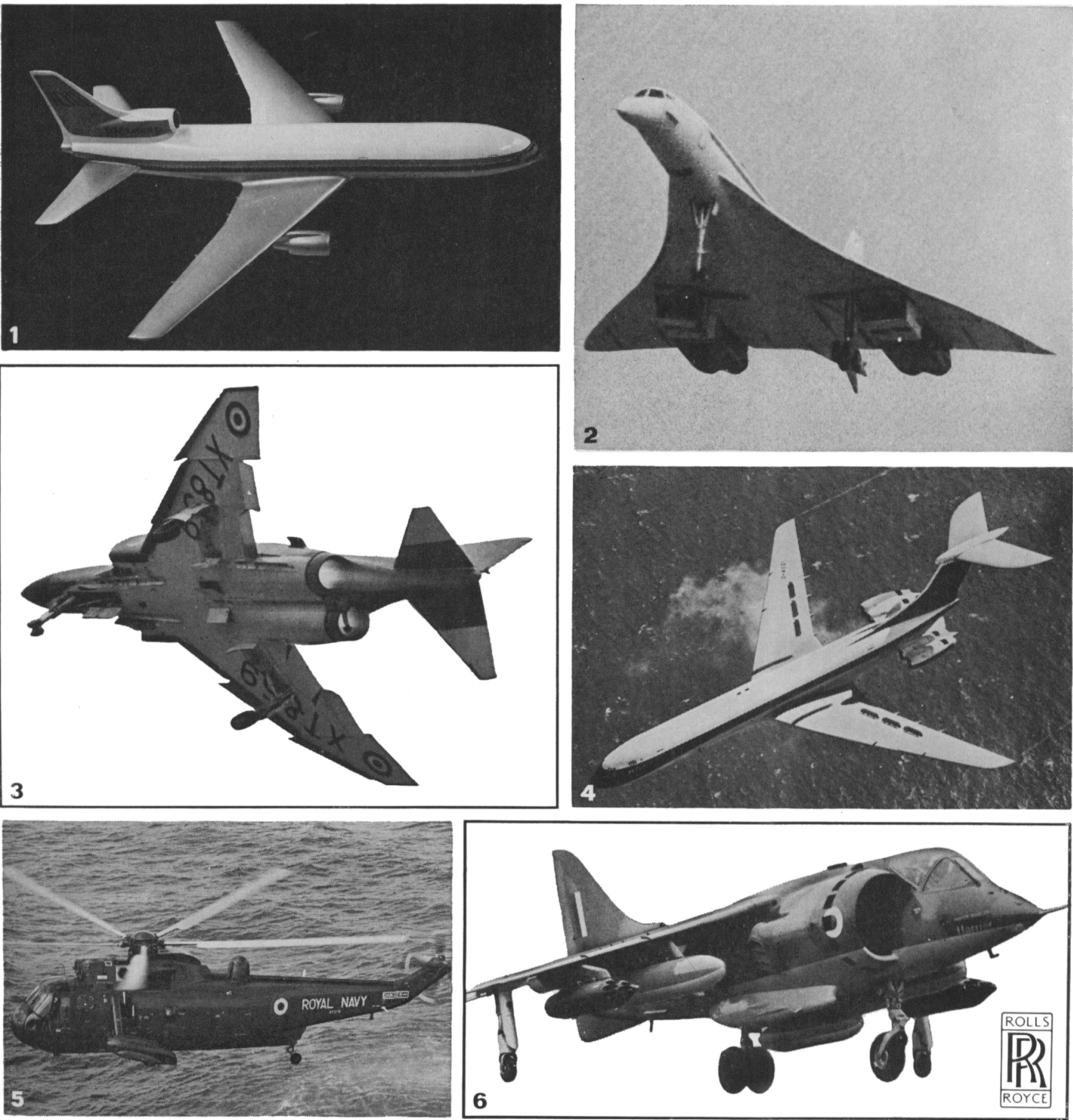

ROLLS-ROYCE LIMITED · DERBY · ENGLAND · Aero Engine Division · Bristol Engine Division · Small Engine Division

THE AERONAUTICAL JOURNAL OF THE ROYAL AERONAUTICAL SOCIETY] 3

IADVERTISEMENTS JUNE 1969 


\section{We put 8 ounces of tungsten carbide in this engine}





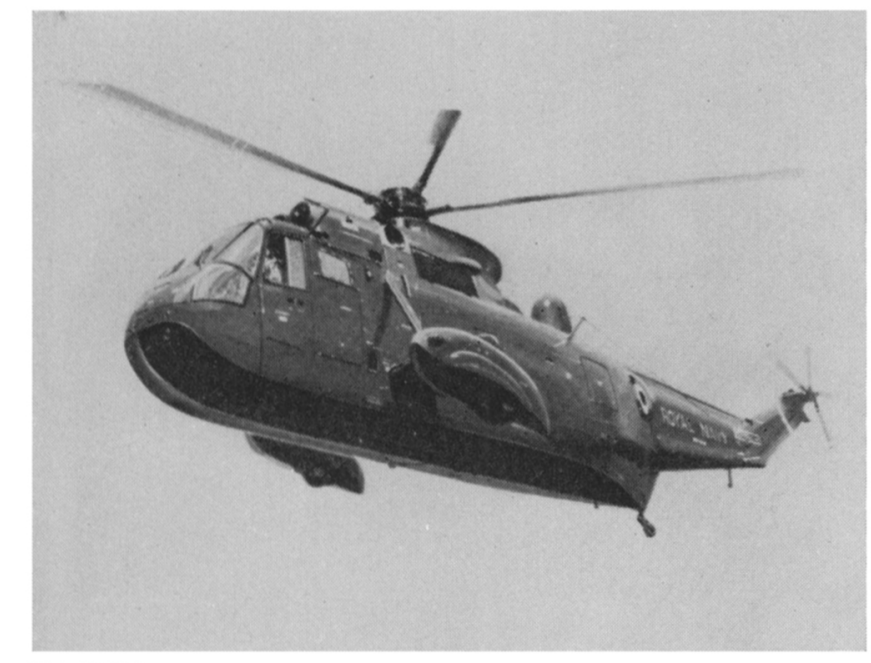

SEA KING

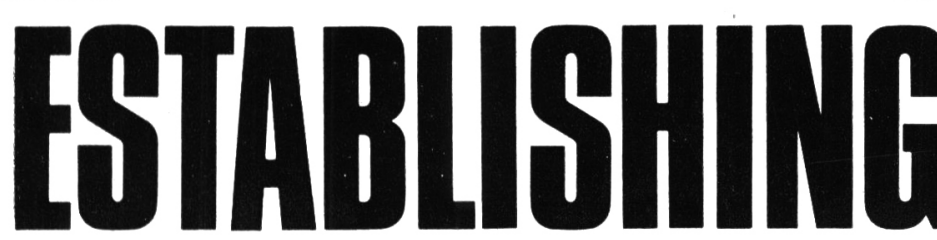

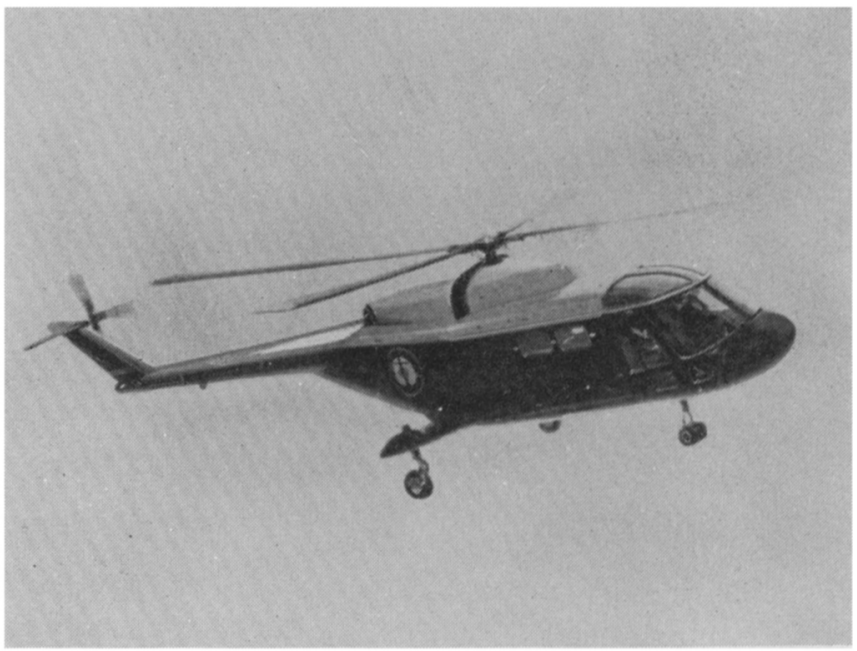

WG.13
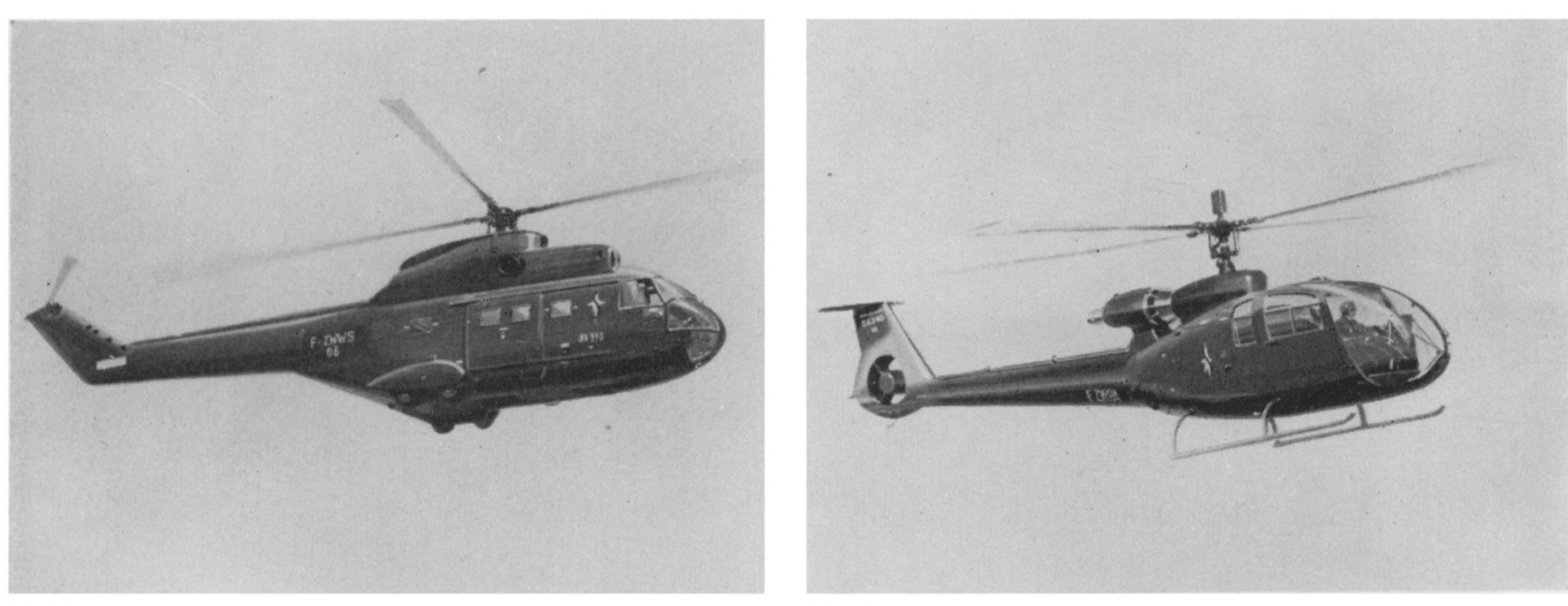

Anglo-French Co-operation sets the pattern of Westland Helicopter development and production for the next decade.

The Westland WG.13, a new and advanced helicopter of all-British design, plays a significant part in the helicopter agreement under which Westland Helicopters Limited and Sud Aviation are co-operating to provide the British and French Armed Forces with general-purpose, armed reconnaissance, anti-submarine, tactical support and light helicopters for the 1970's.

The Westland contribution to the Anglo-French helicopter programme will maintain continuity between the large order for the Sea King advanced anti-submarine helicopter and Westland's future rotorcraft projects.

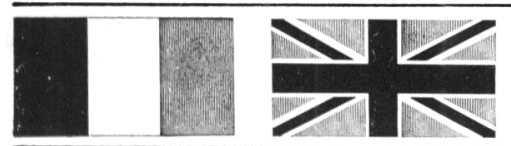

ADVERTISEMENTS JUNE 1969]

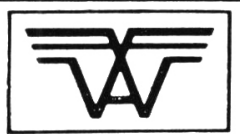

WESTLAND HELICDPTERS LIMITED

YEOVIL SOMERSET ENGLAND

SUBSIOIARY OF WESTLAND AIRCRAFI LIMITEO 

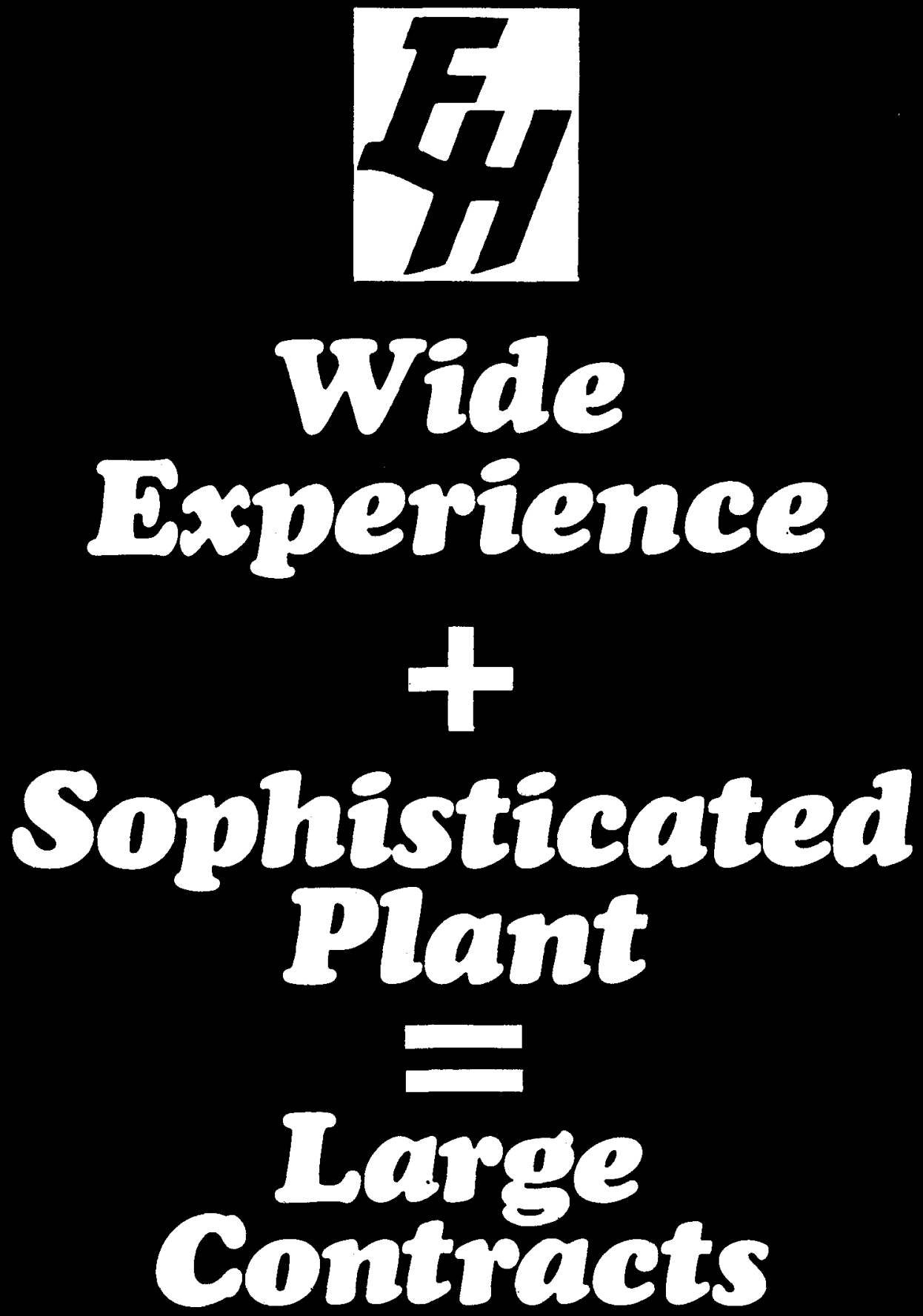

From Menasco Manufacturing Co to E.H. a contract to supply hydraulic components

From Handley Page Lid to E. H., a contract for for the Lockheed TriStar.

landing gear and hydraulic equipment for the Jetsiream.

\section{FLECTRO- W YDRaUlics-a company to count on:} ELECTRO-HYDRAULICS LIMITED - WARRINGTON, LANCASHIRE - TELEPHONE: 35922 - TELEX: 62145 - GRAMS: HYDRAULICS WARAINGTON STAND NO. $7 \cdot 28 \mathrm{mme}$ SALON INTERNATIONAL de l'AERONAUTIOUE et de l'ESPACE 


\section{Bvery single military and oivil airiteld in the word is lonown, and targeted}

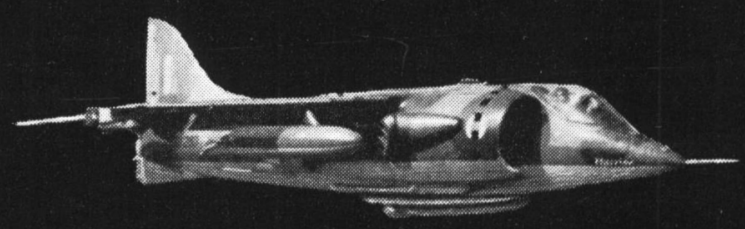

The Harrier alone is not dependent on airfields.

F Hawker Siddeley-the largest aerospace group in Europe

Richmond Road, Kingston upon Thames, Surrey, England. Tel:01:546 7741. Cables: Hawsidair, Kingstonupon Thames. Telex: 23726

Hawker Siddeley Group supplies mechanical,electrical and aerospace equipment with world-wide sales and service 